ДО ПРОБЛЕМИ ЗАСТОСУВАННЯ ДИСТАНЦІЙНОЇ ОСВІТИ ТА Е-ОСВІТИ У СУЧАСНИХ УМОВАХ

\title{
TO THE PROBLEM OF APPLICATION OF DISTANCE EDUCATION AND E-EDUCATION IN MODERN CONDITIONS
}

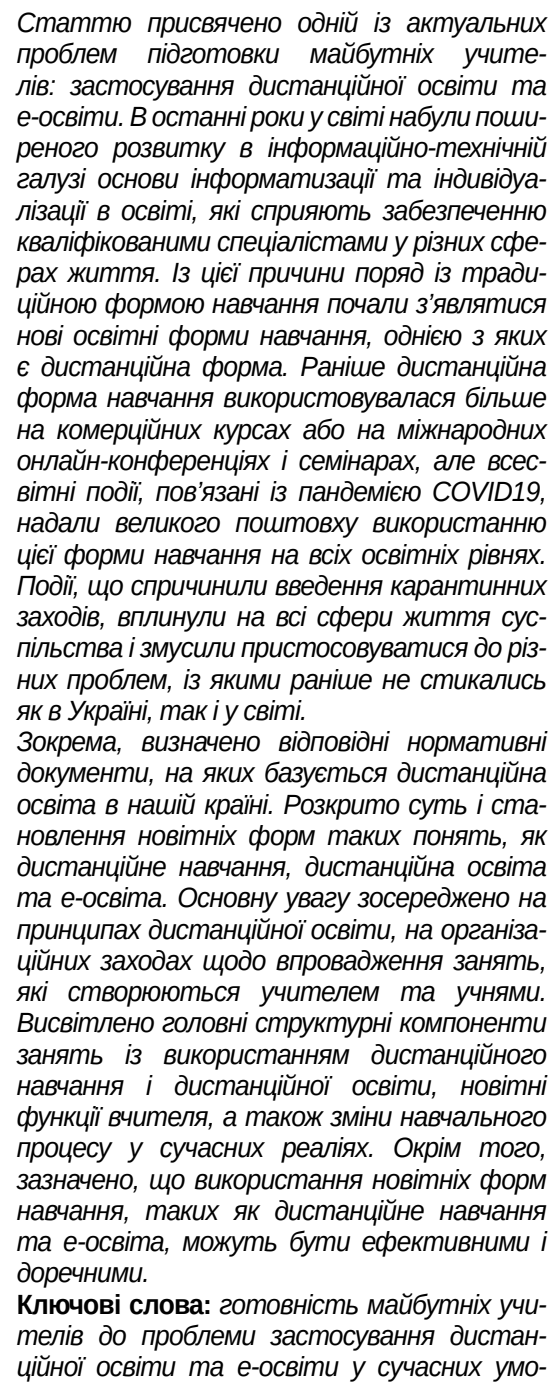

Статтю присвячено одній із актуальних проблем підготовки майбутніх учителів: застосування дистанційної освіти та -освіти. В останні роки у світі набули поши галузі основи інформатизації та індивідуалізації в освіті, які сприяють забезпеченню Hux copeчійною соромс нові освітні форми навчання, однією з яких дистанційна орорма. Раніше дистанційна на комериійних курсах або на міжнародних онлайн-консреренціях і семінарах, але всесвітні події, пов'язані із пандемією COVID19, Події, що спричинили введення карантинних заходів, вплинули на всі сорери життя сусст в і змусили пристосовуватися до різних проблем, із якими раніше не стикались

олкрема, визначено відповідні нормативні освіma в наuій край. Pозкрито суmь і сmaновлення новітніх фоом таких понять, як дистанційне навчання, дистанційна освіта осліта основну увагу зосереджено на принципах дистанційної освіти, на організажах заходах щодо впровадження занять,

Удк 378.091.3

DOI https://doi.org/10.32843/2663-

6085/2021/41/2.16

Поршнева К.С.,

аспірантка кафедри початкової

і профресійної освіти

Харківського національного

педагогічного університету

імені Г.С. Сковороди вах освіти у синхронному та асинхронному режимі часу.

The article is devoted to one of the urgent problems of preparation of future teachers for the application of distance education and e - education. In recent years, the basics of informatization and individualization in education have become widespread in the world in the field of information technology. They assist in providing qualified professionals in various walks of life. For this reason, new forms of education began to appear alongside the traditional form of education. One of them is distance learning. In the past, distance learning has been used more in commercial courses or international online conferences and seminars, but global events related to the COVID19 pandemic have given a big boost to the use of this form of learning at all levels of education. Of course, the events caused by the introduction of quarantine measures have affected all spheres of society and led to adapt to various problems that have not previously been faced in Ukraine and in the world.

In particular, the relevant regulations on which distance education in our country is based have been identified. The essence and formation of the newest forms of such concepts as distance learning, distance education and e - education are revealed. The main focus is on the principles of distance education, organizational arrangements for classes created by teachers and students. The main structural components of classes with the use of distance learning and distance education, the latest functions of the teacher, as well as changes in the educational process in modern realities are covered. It is also noted that the use of the latest forms of learning, such as distance learning and e-education, can be effective and appropriate.

Key words: readiness of future teachers to the problem of application of distance education and $e$-education in modern conditions of education in synchronous and asynchronous mode of time.
В останні роки у світі набули поширеного розвитку в інфрормаційно-технічній сфері основи інфрорматизації та індивідуалізації в освіті, які сприяють забезпеченню кваліфікованими спеціалістами у різних сорерах життя. Із цієї причини поряд із традиційною фрормою навчання почали з'являтися нові освітні форми навчання, однією з яких є дистанційна фрорма.

Раніше дистанційна фрорма навчання використовувалася більше на комерційних курсах або на міжнародних онлайн-конференціях та семінарах, але всесвітні події, пов'язані із пандемією COVID19, надали великого поштовху використанню цієї орорми навчання на всіх освітніх рівнях. Події, що спричинили введення карантинних заходів, вплинули на всі сорери життя суспільства і змусили пристосовуватися до різних проблем, із якими раніше не стикались як в Україні, так і у світі.

Дистанційна форма навчання у нашій країні базується на таких нормативних документах:

- Національній доктрині розвитку освіти [10];

- Національній стратегії розвитку освіти в Україні на період до 2021 року [11];

- Положенні про дистанційне навчання (зі змінами, внесеними згідно з наказами Міністерства освіти і науки № 660 від 01.06.2013, № 761 від 14.07.2015) [8];

- Наказі Міністерства освіти і науки України «Про затвердження Положення про дистанційне навчання (зі змінами, внесеними згідно з Наказами Міністерства освіти і науки № 1115 від 08.09.2020)» [5]; 
- Концепції Державної цільової програми впровадження в навчально-виховний процес загальноосвітніх навчальних закладів інфрормаційно-комунікаційних технологій «Сто відсотків» на період до 2015 року [4].

Дистанційна форма навчання $€$ основою дистанційної освіти.

У науковій літературі дистанційна освіта має різні трактування значення. Наприклад, В.Ю. Биков та інші педагоги ( Ю.М. Богачков, В.М. Кухаренко, О.В. Рибалко, Н.Г. Сиротенко) у своєму посібнику «Технологія створення дистанційного курсу» стверджували, що дистанційне навчання - це фрорма організації та реалізації навчально-виховного процесу, за якою його учасники (об'єкт і суб'єкт навчання) здійснюють взаємодію принципово і переважно екстериторіально, що означає «бути на відстані» та не дозволяє і не передбачає безпосередню навчальну взаємодію учасників віч-на-віч. Інакше кажучи, якщо учасники територіально знаходяться поза межами можливої безпосередньої навчальної взаємодії, та коли під час навчання їхня особиста присутність у певних навчальних приміщеннях навчального закладу не є обов'язковою.

Передумовою появи дистанційної освіти стала монографрія В.Ю. Бикова «Моделі організаційних систем відкритої освіти», де дистанційна освіта виступає як інструмент реалізації принципів відкритої освіти [2].

Проаналізувавши наукові джерела, було виявлено, що в Європі у XIX столітті стає поширеним поняття «кореспондентське навчання», тобто «навчання на відстані». У 20-х роках XX століття В Україні виник різновид кореспондентського навчання - заочного навчання, що широко використовувалось у закладах освіти різного типу. У 1982 році під час Міжнародної конференції у Канаді термін «кореспондентське навчання» було змінено на термін «дистанційна освіта» [2].

Освітній процес здійснюється переважно дистанційно та за допомогою використання електронних засобів навчання. Дистанційна освіта набула своєї специфріки, яка базується на таких принципах, як:

- можливість безперервної освіти незалежно від часу і місця знаходження;

- можливість обирати учнями загальноосвітні заклади, які найбільш забезпечують досягнення мети і можливість здобувати освіту, обирати навчальні дисципліни, викладацький склад;

- зміна деяких фрункцій вчителя (посилення організаційно-виховної фрункції, зменшення комунікативної функції спілкування з учнями та з колегами, розвивається більша спрямованість на організаційну основу навчання та на збільшення самостійної роботи учнів);

- навчання здійснюється у різних фрормах (урочна, вечірня, позаурочна, екстерном);
- доступ до інорормаційного забезпечення у зручний час;

- створення умов до самовдосконалення знань і навичок стосовно інформаційно-технічного прогресу;

- використання спеціальних базових програм, спеціальних платорорм;

- підвищення кваліфрікації роботи із комп'ютерними технологіями;

- освіта стає більш інтерактивною і мультимедійною;

- створення умов для організації свого навчального процесу у зручний для себе час;

- надання можливості економити час і робити його більш продуктивним;

- можливість здобувати освіту за коротший термін, ніж тоді, коли навчання здійснюється у традиційній фрормі навчання;

- створення сприятливих умов для контролю знань і впровадження нових методів та прийомів контролю знань за допомогою сучасних технічних тенденцій;

- збільшення можливості психологічного комфрорту учнів під час навчання;

- поліпшення умов адаптаційного періоду;

- створення сприятливих умов для навчання;

- запровадження індивідуального підходу до суб'єктно-суб'єктної взаємодії;

- сприяння взаємному обміну інорормацією, знаннями, вміннями і навичками між різними народами і культурами; бами;

- здобуття освіти людьми з особливими потре-

- забезпечення самостійного саморозвитку, самоосвіти, самовдосконалення своїх знань, умінь та навичок, розвиток критичного і творчого мислення, а також пізнавальної активності.

Існує багато визначень терміну «дистанційна форма навчання». Ми схиляємося до такого визначення, що дистанційна форма навчання - це фрорма організації навчального процесу у закладах освіти (ВН3, ЗПО, ПТНЗ, ЗН3), яка забезпечує реалізацію дистанційного навчання та передбачає можливість отримання випускниками документів державного зразка про відповідний освітній або освітньо-кваліфікаційний рівень [5]. Дистанційна фрорма навчання $є$ процесом взаємодії між вчителем та учнем в ізольованому просторі.

В.Ю. Биков та інші педагоги у посібнику «Технологія створення дистанційного курсу» відзначали, що традиційна дистанційна фрорма навчання - це різновид дистанційного навчання, за яким учасники та організатори навчального процесу здійснюють взаємодію переважно асинхронно у часі, значною мірою використовуючи в якості транспортної системи доставлення засобів навчання та інших інформаційних об'єктів системи поштового, телефонного або телеграфного зв'язку [9]. 
У вітчизняних працях проблему дистанційної освіти досліджували такі науковці та педагоги, як В. Биков, О. Глазунова, Н. Думанський, О. Захар, П. Камінська, Г. Кравцова, В. Кухаренко, Н. Молодих, Н. Морзе, К. Обухова, В. Олійник, О. Самойленко, Н. Сиротенко, Н Твердохлєбов та інші.

На думку Є.С. Полат, «дистанційне навчання це взаємодія на відстані вчителя та учня, яка має всі властиві навчальному процесу компоненти (мету, зміст, методи, організаційні фрорми, засоби навчання) і реалізовується специфічними засобами інтернет-технологій або іншими засобами, що передбачають інтерактивність» [7].

Б. Холмберг та О. Сімпсон стверджують, що дистанційне навчання - це «нова специфрічна форма навчання, що передбачає використання певних підходів, методів, дидактичних засобів, взаємодії учителя та учнів» $[13,14]$.

Дистанційна освіта базується на нових сучасних тенденціях і дає змогу отримати вільний доступ до інфрормації, потрібної для навчання. Важливою умовою успішного впровадження у навчальну сореру життя людини $€$ не лише організаційні заходи, які застосовує вчитель, але і організація роботи учня, а саме:

- психологічне налаштування особистості учня на отримання нових знань, умінь і навичок;

- взаємодія учня з учителем під час занять;

- підготовка робочого місця учня;

- підготовка зовнішнього вигляду учня;

- налаштування сучасних гаджетів на робочий режим (ноутбуків, планшетів, телефонів, камер, Інтернет, кабелю, додаткового підключення гаджетів);

- виконання домашньої роботи із застосуванням сучасних гаджетів;

- налаштування самостійної роботи самим учнем;

- контроль учня з боку батьків під час онлайнзанять, виконання домашніх завдань і самостійної роботи;

- співпраця учителя і батьків.

Звичайно, не лише учні, але і вчитель мають організувати навчальний процес, особливо тому, що дистанційна освіта передбачає планування та організацію 3 набагато більшими нюансами, ніж традиційна форма навчання. Тому вчитель здійснює підготовку таких складників уроку, як:

- підготовка плану занять;

- підготовка навчального матеріалу (програм, освітніх сайтів, освітніх платформ, додатків, технічних засобів);

- застосування різних фрорм організації навчального процесу (традиційного та нетрадиційного уроку);

- застосування різних фрорм занять (індивідуальних і групових);

- підбір інтерактивних методів і прийомів, таких як технології проблемного навчання, кейс-метод, методи стимулювання творчої активності, навчально-творчі завдання, метод мозкової атаки, навчання в малих групах, навчальний тренінг та ігровий метод;

- використання сучасних інформаційних технологій (мультимедійних презентацій, інтерактивних дошок, електронних підручників);

- завантаження навчальних матеріалів на сайти, блоги, платформи, у хмарне сховище;

- забезпечення цілодобового доступу до навчального матеріалу;

- організація керування навчальним процесом (консультації, контроль за виконанням навчальних завдань, спостереження, рекомендації щодо виконання завдань, перевірка виконання завдань);

- підготовка домашньої роботи для учнів (завдання для самостійної роботи учнів із поясненнями, рекомендаціями та консультаціями із приваду виконання);

- підтримання розвитку самостійності та саморозвитку учня під час навчання;

- організація батьківського контролю виконання домашньої роботи учнями.

Унаслідок того, що організація освітнього процесу під час дистанційного навчання відрізняється від традиційної фрорми навчання, почали змінюватися та розширюватися функції вчителя, а також додаватися нові функції вчителя, такі як:

- консультативна фрункція;

- фрункція спостерігача-куратора або коучера;

- функція контролю за виконанням і здійсненням конкретної мети під час навчання в асинхронному часі тощо.

Навчально-виховний процес під час дистанційної освіти здійснюється переважно синхронно у часі (коли учасники навчання взаємодіють в однаковому часі) та асинхронно у часі (коли учасники навчання можуть не взаємодіяти в однаковому часі) [9]. Водночас забезпечується можливість упровадження дистанційної фрорми навчання за допомогою традиційної дистанційної форми [9].

Нині з'явилися різні навчальні курси, вебінари, марафони, відео-заняття, спрямовані на розвиток учня. Ці заняття дозволяють отримувати освіту, навички та нові знання, не відвідуючи заклади освіти, у вільному часовому режимі, виконувати завдання самостійно чи їх виконувати, а потім здавати на перевірку спеціалісту 3 цієї галузі освіти. Водночас надається можливість отримувати завдання, інформацію і можливість самому розподіляти свій навчальний час. На цих заняттях учитель виступає у ролі наставника, функціями якого $€$ :

- зацікавлення;

- консультування;

- надання порад;

- стимулювання;

- спрямування на правильний шлях; 
- об'єктивне і профресійне доведення плюсів

і мінусів виконання завдань;

- висвітлення термінів здачі завдань;

- створення умов для виконання різноманітних освітніх завдань;

- організація освітнього процесу.

Поряд із упровадженням дистанційної освіти використовується електронна освіта або е-освіта (за аналогією, е-суспільство, е-уряд тощо) - це різновид дистанційної освіти, за яким учасники та організатори навчального процесу здійснюють переважно індивідуалізовану взаємодію як асинхронно, так і синхронно у часі, переважно і принципово використовуючи електронні транспортні системи доставлення засобів навчання та інших інорормаційних об'єктів, комп'ютерні мережі Інтернет / Інтранет, медіанавчальні засоби та інформаційно-комунікаційні технології (IКT) [9].

Е-освіта або електронна освіта - це напрямок дистанційної освіти, тому використовується як додаткова фрорма навчально-виховного процесу дистанційної освіти.

Використання е-освіти у науковій літературі трактується як різновид освітньої системи, в якій навчально-виховний процес переважно підтримується технологіями електронно-дистанційного навчання, а організація освітнього процесу забезпечує реалізацію принципів відкритої освіти [9].

Виникнення е-освіти спричинило створення і застосування спеціальних програмних засобів інформаційних систем е-дистанційного навчання 3 метою поліпшення умов суб'єктно-суб'єктної взаємодії під час навчання. Інфрормаційні системи надали змогу забезпечити підтримку навчального процесу внаслідок розширення можливості використання програмного забезпечення, користування інорормаційним полем із можливістю отримувати навчальну інформацію, зберігати ії та переробляти.

Створення і використання інфрормаційно-освітнього середовища $є$ зовсім новим етапом розвитку е-освіти, що спирається на міжнародні та національні стандарти та відповідає таким нормам, як:

- можливість надання єдиного і швидкого пошуку закладів освіти незалежно від місця їх знаходження;

- універсальний перелік освітніх серверів із можливістю доступу до них;

- використання різних програм освіти і додатків.

Якщо порівняти дистанційну освіту та е-освіту, то різниця в тому, що дистанційна освіта впроваджується не лише за допомогою Інтернет-ресурсів, але і за використання різних фрорм взаємодії суб'єктів освітнього процесу у синхронному та в асинхронному режимі, тоді як е-освіта здійснюється тільки за допомогою Інтернет-ресурсів.

Однією 3 важливих позитивних рис дистанційної освіти та е-освіти є навчання і розвиток у різних сорерах життя, не користуючись водночас лише традиційною фрормою занять. Кожна людина незалежно від статі, нації, мови, культури, віросповідання, а також люди із різними вадами здоров'я можуть отримувати знання із різних сорер життя, таких як:

- профресійний ріст;

- особистий ріст;

- духовний ріст;

- фрізичний зріст;

- поліпшення здоров'я;

- поліпшення фрінансового благополуччя.

Такий формат освіти нині набуває великого попиту у населення. Дистанційна освіта та е-освіта мають позитивні тенденції розвитку. Але виникає питання про те, що їхній розвиток спричинює появу задач, із якими сучасні вчителі не стикались, а також показує, що освіта не встигає за сучасним темпом життя і ростом технічного прогресу. Дистанційна освіта стає неефективною, якщо:

- відсутні освітні програми із дисциплін, які викладаються у дистанційному режимі;

- не вистачає базового матеріалу для викладання у дистанційному режимі;

- немає організації різних фрорм викладання навчального матеріалу у межах дистанційної освіти;

- не запроваджуються сучасні методи і прийоми навчання;

- не підтримується навчальний інтерес і мотиваційний компонент навчання;

- відсутні вміння організовувати самостійну роботу учнів;

- немає спеціальних та базових джерел наукової літератури (методичних рекомендацій, посібників, електронних бібліотек, фондів та архівних сховищ);

- дефіцит кваліфікованих педагогічних працівників, здатних працювати на технічному обладнанні, із сайтами, освітніми платорормами; не здійснюються навчальні курси, тренінги, семінари із підвищення кваліфікації педагогічних працівників;

- недостатня кількість технічних ресурсів (сайтів, платформ, додатків для роботи у дистанційному режимі, хмарних сховищ, освітніх серверів);

- відсутня технічна підтримка власників освітніх серверів і встановлення ліцензійних обмежень щодо використання сервером;

- погіршення стану здоров'я і психологічне навантаження як учителя, так і учнів;

- відсутня якість і швидкість технічного оснащення, гаджетів та доступу до Інтернету (мікрофронів, камер, звукових колонок, мікшерних пультів, навушників, шнурів);

- відсутність комунікації між учнями із можливістю передачі інформації один одному.

Отже, розвиток освіти призвів до появі різних її фрорм, які поряд із традиційною фрормою 
викладання здійснюються віддалено, тобто взаємодія учителя та учнів здійснюється в асинхронному та синхронному режимі часу.

Стає доречним та ефрективним упровадження в освіту дистанційного навчання та е-освіти, які дозволяють розвиватись освіті у цьому напрямку, використовуючи сучасні інфрормаційно-технічні засоби. Безумовно, інфрормаційні джерела оновлюються дуже швидко, тому освіта не встигає за сучасними тенденціями у цьому напрямку, що стає для неї перешкодою. Проте дистанційна освіта та е-освіта можуть позитивно вплинути на розвиток сучасної освітньої системи.

\section{БІБЛІОГРАФІЧНИЙ СПИСОК:}

1. Биков В. Ю. Дистанційна навчання. Енциклопедія освіти України. Акад. пед. наук України / за ред. В. Г. Кремень. Київ : Юрінком Інтер, 2008. C. 191-193.

2. Биков В. Ю. Моделі організаційних систем відкритої освіти : монографрія. Київ : Атіка, 2008. 684 с.

3. Жмуд О. В., Чирва Г. М. Використання технологій дистанційного навчання як засіб підвищення якості навчання інорормаційних дисциплін іноземних студентів. Вісник Житомирського державного університету імені Івана Франка. 2017. С. 78-84.

4. Концепції Державної цільової програми впровадження у навчально-виховний процес загальноосвітніх навчальних закладів інфрормаційно-комунікаційних технологій "Сто відсотків" на період до 2015 року. URL: https://zakon.rada.gov.ua/laws/show/1722-2010-p

5. Міністерство освіти і науки України. Наказ Про затвердження Положення про дистанційне навчання (зі змінами, внесеними згідно з Наказами Міністерства освіти і науки № 1115 від 08.09.2020). URL: https://zakon.rada.gov.ua/laws/show/z0703-13

6. Міністерство освіти і науки. Академія педагогічних наук України. Національна доктрина розвитку освіти України у XXI столітті. Київ : "Шкільний світ", 2001. 24 C.

7. Моїсеєва М. В, Петров А. Є., Полат Є. С. Педагогічні технології дистанційного навчання / за ред. €. С. Полат. Москва : Академія, 2006. 400 с.

8. Положення про дистанційне навчання (зі змінами, внесеними згідно з наказами Міністерства освіти і науки № 660 від 01.06.2013, № 761 від 14.07.2015). URL: https://zakon.rada.gov.ua/laws/ show/z0923-15

9. Биков В.Ю. та ін. Технологія створення дистанційного курсу : навч. посіб. Київ : Міленіум, 2008. $324 \mathrm{c}$.

10. Указ президента України Про Національну доктрину розвитку освіти. URL: https://zakon.rada.gov. ua/laws/show/347/2002.

11. Указ Президента України Про Національну стратегію розвитку освіти в Україні на період до 2021 року. URL: https://zakon.rada.gov.ua/laws/show/ 344/2013.

12. Шиліна Г. А. Методика дистанційного навчання української мови учнів основної школи : дис. ... канд. пед. наук : 13.00.02. Київ, 2016. 300 с.

13. Holmberg B. The Evolution, Principles and Practices of Distance Education. Oldenburg : Bibliotheks und Informationssystem der Universitat Oldenburg, 2005. P. 57.

14. Simpson O. Supporting students in online, open and distance learning. London : Kogan page Limited, 2002. 237 p. 